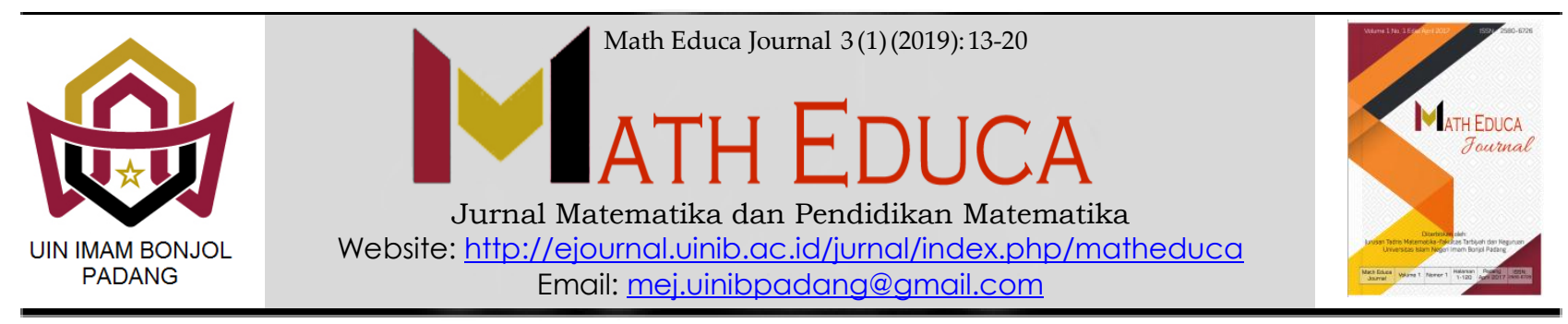

\title{
PENERAPAN MODEL CONTEX TUAL TEACHING AND LEARNING (CTL) DALAM PEMBELAJARAN MATEMATIKA UNTUK MENINGKATKAN KEMAMPUAN PEMECAHAN MASALAH MATEMATIS PESERTA DIDIK KELAS VII SMPN 1 DANAU KEMBAR
}

\author{
'Dianti Yahya, 2 Yulia \\ 1,2Tadris Matematika, Fakultas Tarbiyah dan Keguruan, UIN Imam Bonjol Padang, Indonesia \\ Email: Diantyyahya50@gmail.com,2yuliyay099@ymail.com
}

Received: January 2019; Accepted: March 2019; Published: April 2019

\begin{abstract}
Abstrak
Model pembelajaran yang dipilih pendidik belum mampu mengakomodasi kemampuan pemecahan masalah matematika peserta didik. Untuk itu diterapkan model Contextual Teaching and Learning $(\mathrm{CTL})$. Penelitian ini bertujuan untuk mengetahui perbandingan kemampuan pemecahan masalah matematis peserta didik yang diajarkan denan menggunakan model Contextual Teaching and Learning (CTL) dan menggunakan model pembelajaran biasa (pendekatan saintifik). Jenis penelitian ini adalah Quasy Experiment dengan rancangan penelitian adalah Randomized Control Group Only Design. Populasi dalam penelitian ini adalah seluruh peserta didik kelas VII SMPN 1 Danau Kembar. Penarikan sampel dilkakukan dengan teknik random sampling. Instrumen yang digunakan adalah tes kemampuan pemecahan masalah matematis. Berdasarkan hasil penelitian diperoleh rata-rata kemampuan pemecahan masalah matematis peserta didik kelas eksperimen dan kelas kontrol adalah 80,30 dan 73,16. Selanjutnya dilakukan uji hipotesis dengan menggunakan uji-t. Dari perhitungan diperoleh $t_{\text {hitung }}>t_{\text {tabel }}(2,21>1,64)$ dengan $\alpha=0,05$ pada selang kepercayaan $95 \%$, maka $H_{0}$ ditolak dan $\mathrm{H}_{1}$ diterima artinya hipotesis diterima.
\end{abstract}

Kata Kunci : Kemampuan Pemecahan Masalah Matematis, Contextual Teaching and Learning. (CTL)

\section{Abstract}

Learning model chosen by educators teacher has not been able to accommodate the mathematics problems of students. For that, the Contextual Teaching and Learning (CTL) model was applied. The purpose of research is to collation the mathematical problem solving abilities of students who are using Contextual Teaching and Learning (CTL) learning model and using the ordinary learning model (scientific approach). This type of research is a quasy experiment with randomized control group only design. The population of this study were all students of class VII SMPN 1 Danau Kembar. For to get sample class with random sampling technique. As for the research instrument used in the study is a test of mathematical problem solving students abilities. Based on the results of this avarage mathematical problem solving students abilities experiment class and

\footnotetext{
*Corresponding author.

Peer review under responsibility UIN Imam Bonjol Padang.

(c) 2019 UIN Imam Bonjol Padang. All rights reserved. 
control class is 80,30 and 73,16 . Than the hypothesis testing using the t-test. From calculation result obtained t_count $>t_{-}$table $2,21>1,64$ ) with $\alpha=0,05$ with $95 \%$ confidence interval so $\mathrm{H}_{0}$ rejected and accepted $\bar{H}_{1}$.

Keywords : Mathematical problem solving abilities, Contextual Teaching and Learning (CTL)

\section{PENDAHULUAN}

Kemampuan dasar dalam pembelajaran matematika yang harus dikuasai oleh peserta didik sesuai dengan tujuan kurikulum matematika di Indonesia ada lima untuk memperoleh hasil belajar yang baik, diantaranya kemampuan pemecahan masalah; kemampuan penalaran dan bukti; kemampuan komunikasi; kemampuan koneksi; dan kemampuan representasi. Jihad dalam Sepriyanti (2015: 105-106).

Kemampuan dasar yang harus dikuasai dan tujuan harus dicapai adalah peserta didik memiliki kemampuan memecahkan masalah matematis. Kemampuan memecahkan masalah adalah sarana untuk mengasah kemampuan berpikir logis, kreatif, analitis, dan krisis, sehingga dapat mengembangkan pola pikirnya dalam memecahkan suatu permasalahan matematika.

Pemecahan masalah adalah proses menerapkan pengetahuan yang telah diperoleh sebelumnya ke dalam situasi baru yang belum dikenal. Menurut Letner dalam Mulyono (2003:253) pemecahan masalah merupakan bagian dari kurikulum matematika yang sangat penting karena dalam proses pembelajaran maupun penyelesaian, peserta didik dimungkinkan memperoleh pengalaman menggunakan pengetahuan serta kemampuan yang dimilikinya dalam menyelesaikan masalah matematis terkait dunia nyata yang bersifat non rutin.

Pemecahan masalah adalah proses menerapkan pengetahuan yang telah diperoleh sebelumnya ke dalam situasi baru yang belum dikenal. Pada pemecahan masalah matematika akan memberikan peserta didik kesempatan untuk melakukan investigasi masalah matematika yang mendalam, sehingga dapat mengkonsruksi segala kemungkinan pemecahannya secara kritis, dan kreatif.

Faktanya tujuan pembelajaran matematika di sekolah kurang tercapai dengan maksimal. Berdasarkan hasil observasi yang telah dilakukan penulis di SMPN 1 Danau Kembar pada tanggal 24 Agustus 2018, terlihat bahwa pembelajaran masih didominasi oleh pendidik (pembelajaran satu arah). Pendidik memulai pembelajaran dengan menjelaskan materi pembelajaran yang disertai dengan contoh-contoh soal. Pembelajaran juga disertai dengan tanya jawab serta pemberian soal latihan yang dibahas secara bersama-sama. Pada akhir 
pembelajaran, pendidik dan peserta didik mencoba menyimpulkan materi tersebut dan pendidik memberikan pekerjaan rumah

Penyebab rendahnya kemampuan pemecahan masalah matematis peserta didik juga disebabkan peserta didik terbiasa mengerjakan soal yang didasarkan pada contoh soal. Ketika diberikan soal cerita peserta didik mengalami kesulitan dalam menjawabnya. Kesalahannya terlihat pada langkah-langkah penyelesaian yang telah dibuat peserta didik. Seharusnya peserta didik menyelesaikan soal sesuai dengan indikator kemampuan pemecahan masalah yaitu: Memahami masalah, merencanakan penyelesaian, menyelesaikan masalah sesuai dengan rencana, kemampuan pengecekan kembali terhadap semua langkah yang telah dikerjakan.

Salah satu solusi untuk memperbaiki kemampuan pemecahan masalah adalah menggunakan model pembelajaran yang dianggap bisa mengatasi permasalahan tersebut. Model pembelajaran dapat diartikan sebagai kerangka konseptual yang melukiskan prosedur yang sistematis dalam mengorganisasikan pengalaman belajar untuk mencapai tujuan belajar tertentu dan berfungsi sebagai pedoman para perancang pembelajaran dan para pendidik untuk merencanakan dan melaksanakan aktivitas pembelajaran (Aunurrahman 2012:146).
Model pembelajaran yang tepat agar proses belajar mengajar berlangsung efektif dan efesien sehingga seluruh peserta didik dapat terlibat langsung secara aktif, mampu memahami serta menguasai pelajaran matematika, dan peserta didik mempunyai kemampuan pemecahan masalah matematis. Model pembelajaran yang dapat diterapkan adalah Model Contextual Teaching and Learning ( $C T L)$. Johnson dalam Sepriyanti (2016 :23) mengatakan model Contextual Teaching and Learning (CTL) merupakan proses pendidikan yang bertujuan membantu peserta didik melihat makna dalam pelajaran yang mereka pelajari dengan cara menghubungkan dengan konteks kehidupan sehari-hari. Shoimin (2016: 41) juga mengatakan dengan model Contextual Teaching and Learning ( $C T L)$ pendidik mengaitkan materi yang diajarkannya dengan situasi dunia nyata peserta didik dan mendorong peserta didik membuat hubungan antara pengetahuan yang dimilikinya dengan penerapannya dalam kehidupan mereka sebagai anggota keluarga dan masyarakat. Tugas pendidik adalah mengelola kelas agar kelas menjadi kondusif untuk belajar peserta didik.

Materi pelajaran akan tambah berarti jika peserta didik mempelajari materi yang disajikan melalui konteks kehidupan peserta didik, dan menemukan arti di dalam proses 
pembelajarannya, sehingga pembelajaran akan lebih berarti dan menyenangkan.

Berdasarkan uraian di atas, penulis telah melakukan penelitian yang berjudul "Penerapan Model Contextual Teaching And Learning (CTL) Dalam Pembelajaran Matematika Untuk Meningkatkan Kemampuan Pemecahan Masalah Matematis Peserta Didik Kelas VII SMPN 1 Danau Kembar Tahun Pelajaran 2018/2019”. Tujuan penelitian ini adalah untuk mengetahui kemampuan pemecahan masalah peserta didik yang diajarkan dengan model CTL lebih tinggi dibandingkan model pembelajaran biasa (pendekatan saintifik) pada kelas VII SMPN 1 Danau Kembar.

\section{METODE PENELITIAN}

\section{Jenis penelitian}

Jenis penelitian ini adalah eksperimen semu (quasy experiment). Arikunto (2007:207) mengemukakan bahwa penelitian eksperimen merupakan penelitian yang dimaksudkan untuk mengetahui ada tidaknya akibat dari sesuatu yang dikenakan pada subjek selidik. Dengan kata lain penelitian eksperimen mencoba meneliti ada tidaknya hubungan sebab akibat. Caranya adalah dengan membandingkan satu atau lebih kelompok eksperimen yang diberi perlakuan dengan satu atau lebih kelompok pembanding yang tidak menerima perlakuan.
Model rancangan penelitian yang digunakan adalah Randomized control group only design. Dalam rancangan ini sekelompok subjek yang diambil dari populasi tertentu dikelompokkan secara acak menjadi dua kelas yaitu satu kelas eksperimen dan satu kelas kontrol. Rancangan penelitian ini dideskripsikan pada tabel 1.

Tabel 1. Rancangan Penelitian

\begin{tabular}{ccc}
\hline Kelas & Perlakuan & Tes akhir \\
\hline Eksperimen & $\mathrm{X}$ & $\mathrm{T}$ \\
Kontrol & - & $\mathrm{T}$ \\
\cline { 2 - 2 } Sumber: Suryabrata $(2014: 104)$ &
\end{tabular}

\section{Populasi dan Sampel}

Populasi dalam penelitian ini adalah seluruh peserta didik kelas VII SMPN 1 Danau Kembar tahun ajaran 2018/2019 sebanyak 3 lokal dan jumlah peserta didik dalam populasi berjumlah 84 peserta didik.

Sampel yang dipilih dalam penelitian haruslah menggambarkan keseluruhan karakteristik dari suatu populasi, tergambar dalam sampel. Penelitian ini dilakukan terhadap dua kelas yang merupakan wakil dari populasi pada semester ganjil tahun ajaran 2018/2019.

Agar sampel representatif dalam arti segala karakteristik populasi hendaknya tercermin dalam sampel yang diambil, maka rata-rata kelompok sampel harus sama dan homogen. Setelah diketahui bahwa populasi berdistribusi normal, homogen dan rata-rata populasinya sama, maka selanjutnya 
pengambilan sampel dilakukan dengan teknik sampling untuk menentukan dua kelas sampel. Variabel dalam penelitian ini adalah variabel bebas dan variabel terikat. Variabel bebas yaitu model Contextual Teaching and Learning (CTL). Variabel terikat yaitu kemampuan pemecahan masalah matematis peserta didik.

\section{Prosedur penelitian}

Prosedur penelitian dibagi atas tiga tahap yaitu tahap persiapan, tahap pelaksanaan dan tahap akhir. Tahap persiapan dimulai dengan membuat proposal penelitian, menyiapkan rencana pelaksanaan pembelajaran (RPP) dan lembar kerja peserta didik (LKPD), serta mempersiapkan instrument penelitian. Tahap pelaksanaan merupakan waktu pelaksanaan penelitian. Sementara, tahap akhir adalah pemberian tes akhir kepada peserta didik. Tes yang diberikan adalah tes kemampuan pemecahan masalah matematis berbentuk essay yang berjumlah 5 butir.

\section{Data, Instrumen, dan Teknik Pegumpulan} Data

Data adalah hasil pencatatan peneliti, baik yang berupa fakta ataupun angka, Arikunto (2006: 118). Jenis data dalam penelitian ini ada dua yaitu: Data primer, yaitu data yang diperoleh secara langsung oleh penulis dari hasil perlakuan terhadap sampel penelitian. Data primer pada penelitian ini adalah kemampuan pemecahan masalah matematis peserta didik setelah diberikan perlakukan melalui model CTL pada kelas eksperimen dan pembelajaran biasa pada kelas kontrol. Data sekunder, yaitu data yang diperoleh dari orang lain. Dalam hal ini, data sekundernya adalah nilai ulangan harian matematika kemampuan pemecahan masalah matematis seluruh peserta didik kelas VII SMPN 1 Danau Kembar tahun ajaran 2018/2019 dan data jumlah peserta didik yang menjadi sampel dalam penelitian ini.

Data dalam penelitian dapat diperoleh melalui tes yang diberikan kepada kelas sampel. Agar tes yang didapat benar-benar valid, reliable, memperhatikan taraf kesukaran dan daya beda soal, maka terlebih dahulu dilakukan uji coba tes dilakukan analisis soal seperti yang diungkapkan Arikunto (2010: 207) yaitu "Analisis soal bertujuan untuk mengadakan soal identifikasi soal-soal yang baik, kurang baik dan soal yang jelek. Dengan analisis soal dapat diperoleh kejelekan sebuah soal dan petunjuk untuk mengadakan perbaikan".

Instrument yang digunakan dalam penelitian ini adalah tes. Tes yang diberikan sesuai dengan materi pelajaran yang disajikan selama perlakuan berlangsung dan dilakukan setelah penelitian berakhir. Instrumen yang digunakan adalah butir soal tes tertulis berbentuk essay untuk melihat kemampuan pemecahan masalah peserta didik. Adapun indikator soal tes kemampuan pemecahan 
masalah matematika ini dibuat berdasarkan indikator kemampuan pemecahan masalah yaitu: Memahami masalah, merencanakan penyelesaian, menyelesaikan masalah sesuai dengan rencana, kemampuan pengecekan kembali terhadap semua langkah yang telah dikerjakan.

Materi dalam pembelajaran dalam penelitian yaitu "PLSV dan PtLSV". Sebelum tes diberikan kepada kelas sampel, dilakukan uji coba tes. Uji coba tes dilakukan agar memperoleh instrument yang baik. Analisis hasil uji coba soal tes dilakukan dengan menghitung indeks pembeda soal, indeks kesukaran soal, menentukan kriteria penerimaan soal, dan menghitung reabilitas tes. Setelah dilakukan analisis terhadap hasil uji coba soal tes, kemudian dilakukan tes akhir pada kedua kelas sampel untuk melihat kemampuan pemecahan masalah matematis peserta didik tersebut.

\section{Teknik Analisis Data}

Analisis data yang dialakukan dalam penelitian ini adalah analisis deskriptif dan analisis induktif. Analisis desriptif dilakukan untuk menentukan rata-rata dan simpangan baku kedua kelas sampel dan analisis induktif dilakukan untuk melihat apakah terdapat perbedaan dua kelas sampel, ini dilakukan dengan uji t. Untuk melakukan uji t harus dipenuhi dua syarat yaitu sampel berasal dari populasi yang terdistribusi normal dan kedua kelas memiliki varians yang homogen. Oleh sebab itu, terlebih dahulu dilakukan uji normalitas dan homogenitas.

\section{HASIL PENELITIAN DAN PEMBAHASAN}

Hasil analisis tes akhir kemampuan pemecahan masalah peserta didik dapat dilihat dalam tabel 2 berikut:

Tabel 2. Descriptive Statistics

\begin{tabular}{lccccc}
\hline Kelas & $\mathbf{N}$ & $\bar{X}$ & $\mathbf{x}_{\max }$ & $\mathbf{x}_{\min }$ & $\mathbf{S}_{\mathbf{i}}$ \\
\hline Eksperimen & 28 & 80,30 & 98,33 & 58,33 & 11,30 \\
Kontrol & 29 & 73,16 & 93,33 & 53,00 & 13,04 \\
\hline
\end{tabular}

Berdasarkan tabel diatas, dapat dilihat bahwa rata-rata kemampuan pemecahan masalah matematika peserta didik kelas eksperimen dengan menerapkan model Contextual Teaching and Learning (CTL) lebih tinggi dari pada rata-rata kemampuan pemecahan masalah matematika peserta didik kelas kontrol yaitu 7,14. Artinya terjadi peningkatan yang cukup tinggi antara kelas ekperimen dan kelas kontrol yaitu 80,30 dan 73,16 .

Berikut hasil nilai tes akhir pemecahan masalah matematika peserta didik pada masing-masing indikator pada Tabel 3:

Tabel 3. Nilai Tes Akhir Kemampuan Pemecahan Masalah Kelas Eksperimen Dan Kelas Kontrol

\begin{tabular}{|c|c|c|c|}
\hline No & $\begin{array}{c}\text { Indikator Pemecahan } \\
\text { Masalah }\end{array}$ & Eksperimen & Kontrol \\
\hline 1 & Memahami Masalah & 92,14 & 89,20 \\
\hline 2 & $\begin{array}{l}\text { Merencanakan } \\
\text { Masalah }\end{array}$ & 84,76 & 78,85 \\
\hline 3 & $\begin{array}{l}\text { Menyelesaikan } \\
\text { Masalah }\end{array}$ & 86,67 & 77,47 \\
\hline 4 & Pemeriksaan Kembali & 57,62 & 47,13 \\
\hline & Rata-rata & 80,30 & 73,16 \\
\hline
\end{tabular}


Dilihat dari tabel 3 menjelaskan bahwa nilai rata-rata setiap indikator tidak jauh berbeda. Dari deskripsi data diatas dapat dilihat bahwa nilai rata-rata hasil tes akhir pemecahan masalah matematika pada setiap indikator yang paling tinggi peserta didik pada kelas eksperimen setelah itu pada kelas kontrol.

Untuk menarik kesimpulan tentang data kemampuan pemecahan masalah dilakukan analisis data untuk menguji hipotesis yang telah dirumuskan apakah diterima atau ditolak. Untuk mengetahui hal itu terlebih dahulu dilakukan uji normalitas dan uji homogenitas terhadap kemampuan pemecahan masalah matematika peserta didik pada kedua kelas sampel. Setelah diketahui bahwa data berdistribusi normal dan homogen, maka langkah selanjutnya adalah melakukan uji hipotesis melalui uji-t oleh Sudjana (2005 : 239). Uji hipotesis dilakukan untuk mengetahui hipotesis penulisan diterima atau ditolak. Dengan hipotesis statistik:

$H_{0}: \mu_{1} \leq \mu_{2}$

$H_{1}: \mu_{1}>\mu_{2}$

Kriteria $\mathrm{H}_{\mathrm{o}}$ diterima jika $\mathrm{t}_{\text {hitung }}<\mathrm{t}_{(1-} \alpha$ ) dilihat pada tabel distribusi $t$ dengan derajat kebebasan $\mathrm{df}=\mathrm{n}_{1}+\mathrm{n}_{2}-2$ dan peluang $(1-\alpha)$ dan $\mathrm{H}_{\mathrm{o}}$ ditolak jika $\mathrm{t}_{\text {hitung }} \geq \mathrm{t}_{(1-} \alpha$ ) dilihat pada daftar distribusi t dengan derajat kebebasan $\mathrm{df}=\mathrm{n}_{1}+\mathrm{n}_{2}-2$ dan peluang $(1-\alpha)$.
Dari hasil perhitungan di atas, nilai $t_{\text {tabel }}$ pada taraf $\alpha=0,05$ dengan derajat kebebasan $(\mathrm{dk})=55$ diperoleh diperoleh $t_{\text {tabel }}=1,64$ Dengan demikian terlihat bahwa $t_{\text {hitung }}(2,21)>$ $t_{\text {tabel }}(1,64)$. Hal ini berarti bahwa $H_{0}$ ditolak dan $\mathrm{H}_{1}$ diterima. Dengan demikian dapat disimpulkan bahwa kemampuan pemecahan masalah matematika peserta didik yang diajar model Contextual Teaching and Learning (CTL) lebih tinggi dari pada kemampuan pemecahan masalah matematika dengan model pembelajaran biasa (pendekatan saintifik).

\section{SIMPULAN DAN SARAN}

\section{Simpulan}

Berdasarkan hasil analisis data dan pembahasan menunjukkan bahwa terbukti kemampuan pemecahan masalah peserta didik yang menerapkan model model Contextual Teaching and Learning (CTL) lebih tinggi dibandingkan dengan kemampuan pemecahan masalah peserta didik yang menerapkan pembelajaran biasa, dengan nilai rata-rata kemampuan pemecahan masalah kelas eksperimen yaitu 80,30 sedangkan pada kelas kontrol dengan model pembelajaran biasa sesuai dengan K13 yaitu 73,16. Dari pengolahan data kemampuan pemecahan masalah peserta didik dilakukan melalui uji-t, sehingga diperoleh $t_{\text {hitung }}=2,21>t_{\text {tabel }}=1,64$, hal ini berarti hipotesis diterima. 


\section{Saran}

Terdapatnya peningkatan kemampuan pemecahan masalah matematika peserta didik dengan menggunakan model Contextual Teaching and Learning (CTL) ini bisa digunakan sebagai salah satu alternatif bagi guru dalam usahanya meningkatkan kemampuan pemecahan masalah matematika peserta didik. Pendidik matematika SMP/MTs pada umumnya dan pendidik SMPN 1 Danau Kembar pada khususnya dapat menerapkan model pembelajaran Contextual Teaching and Learning ( $C T L)$ disemua kelas. Model Contextual Teaching and Learning (CTL) perlu ditindak lanjuti dengan melakukan penelitian terhadap kemampuan matematika yang lain. Model Contextual Teaching and Learning (CTL) perlu ditindak lanjuti dengan melakukan penelitian pada pokok basan yang lain.

\section{DAFTAR PUSTAKA}

Abdurrahman, Mulyono. 2003. Pendidikan Bagi Anak Berkesulitan Belajar. Jakarta: Rineka Cibta

Al-Qur'anul Karim. 2004. Al-Qur'an dan Terjemahan. Bandung: PT Syaamil Cipta Media.

Sari, Dian Permata, dkk. (2017). Penerapan Model Contextual Teaching Learning Terhadap Kemampuan Pemecahan Masalah Matematis Siswa Kelas XI SMA Negeri 1 Muara Rupit Tahun Pelajaran 2016/2017. Jurnal Ilmiah Pancaran, Vol 2, No. 1, Februari 2017.

Arikunto, Suharsimi. 2006. Prosedur Penelitian Suatu pendekatan praktik. Jakarta: PT. Asdi Mahasatya
Aunurraman. 2012. Belajar dan Pembelajaran. Bandung: Alfabeta.

Hamzah, Ali, dan Muhlisrarini. 2014. Perencanaan dan Strategi Pembelajaran Matematika. Jakarta: PT Raja Grafindo Persada.

Huda, Miftahul. 2013. Model-Model Pengajaran dan Pembelajaran. Yogyakarta: Pustaka Belajar.

Iryanti, Puji. 2004. Penilaian Unjuk Kerja. Yogyakarta: Depdiknas

Jhonson, Elaine B. 2002. Contextual Teaching and Learning. Bandung: Mizan Learning Center.

Jufri, Wahab. 2013. Belajar dan Pembelajaran Sains. Bandung: Pustaka Reka Cipta.

Kunandar. 2013. Penelitian Autentik (Penilaian Hasil Belajar Peserta didik Berdasarkan Kurikulum 2013) Suatu Pendekatan Praktis. Jakarta: PT Raja Grafindo Persada.

Muliyardi. 2003. Strategi Belajar Mengajar. Padang: FMIPA Univ. Negeri Padang.

Nauvilla, Ichda. 2008. Surah al-insyirah dan pemecahan masalah. Skripsi. Universitas islam negeri sunan kalijaga Yogyakarta

Prawironegoro, praktinyo. 1985. Evaluasi hasil belajar khusus analisis soal untuk bidang studi matematika. Jakarta : PLPTK

Priyatno, Dwi. 2009. 5 jam belajar olah data dengan spss 16. Yogyakarta:CV Andi Offset

Rusman. 2014. Model-Model Pembelajaran. Jakarta: PT. Raja Grafindo Persada

Sabri, Ahmad. 2005. Strategi Belajar Mengajar Dan Micro Teaching. Ciputat: Quantum Teaching 
Sanjaya, Wina. 2013. Penelitian Pendidikan. Jakarta: Kencana Prenada Media Group

Sepriyanti, Nana. 2016. Pembelajaran Kalkulus Kontekstual Suatu Modifikasi Model. Jakarta: PT RajaGrafindo Persada.

$\longrightarrow$ 2015. Pengaruh Model Pembelajaran Problem Based Learning Terhadap Kemampuan Pemahaman Konsep Pada Mata Kuliah Statistika Matematika I Mahasiswa Tadris Matematika lain Imam Bonjol Padang. Padang: Prosiding Semnas Mat-PMat STKIP PGRI Sumatera Barat. Vol. 1, No. 1.

,dkk. 2017. Calculus Based On Contextual Learning Model To Cultivate Student's Activity, Interest And Mathematical Connection Ability International Journal of Scientific \& Technology Research (IJSTR). Vol. 6, No.10.

Shihab, M. Quraish. 2002. Tafsir Al-Mishbah pesan kesan dan keserasian Al-Qur'an juz'amma. Jakarta: Lentera Hati
Shoimin, Aris. 2016. 68 Model Pembelajaran Inovatif Dalam Kurikulum 2013. Yogyakarta: Ar-Ruzz Media

Sudjana, Nana. 2004. Dasar-dasar Proses Belajar Mengajar. Bandung: Sinar Baru Algensind

Sudjana. 2005. Metode Statistika. Bandung: Tarsito

Sudjono, Anas. 2006. Pengantar Evaluasi Pendidikan. Jakarta: PT. Raja Grafindo Persada

Sugiyono. 2009. Statistika Untuk Penelitian. Bandung: Alfabeta

Suryabrata, Sumadi. 2004. Metode Penelitian. Jakarta: Raja Grafindo Persada.

Susanto, Ahmad. 2013. Teori Belajar dan Pembelajaran di Sekolah Dasar. Jakarta: KENCANA

Trianto. 2014. Mendesain Model Pembelajaran Inovatif-Progresif. Jakarta: Kencana Prenada Media Group.

Walpole, Ronal E dan Raymond H Myers.1995. Ilmu Peluang Statistika untuk Insinyur dan Ilmuan. Bandung: ITB. 